\title{
Prevention of Dengue Hemorrhagic Fever (DHF) by Planting Lemongrass at SMK 17 Agustus 1945 Surabaya
}

\section{IGAA Noviekayatia), Jeane Putri Amelia, Junike Putri Virgilia, and Lia Zairoh Siska Mawaddah}

\author{
Program Studi Psikologi Profesi (S2), Fakultas Psikologi, Universitas 17 Agustus 1945 Surabaya, \\ Surabaya, Indonesia \\ a)Corresponding author: noviekayati@untag-sby.ac.id
}

\begin{abstract}
Dengue Hemorrhagic Fever (DHF) is a disease caused by the dengue virus which is transmitted through the bite of the Aedes aegypti and Aedes albopictus mosquitoes. Dengue Hemorrhagic Fever (DHF) is caused by the dengue virus and is transmitted by the Aedes aegypti mosquito, which is characterized by a sudden fever of two to seven days without a clear cause, weakness or lethargy, restlessness, heartburn accompanied by signs of bleeding on the skin in the form of bleeding spots, bruising or rashes. sometimes nosebleeds, bloody stools, vomiting blood, decreased consciousness or shock. This PKM aims to provide detailed information about DHF and how to prevent DHF using lemon grass. After participating in this lesson, participants are expected to be able to understand what dengue is, the benefits of lemongrass and know how to plant lemongrass in their neighborhood. The method used in this research is to conduct counseling and distribute pretest and posttest. The results show that this community service program can increase students' knowledge by $64.3 \%$ related to the dangers of dengue fever, the benefits of lemongrass as a mosquito repellent plant and how to plant lemongrass correctly.
\end{abstract}

Keywords: the danger of dengue fever, lemongrass planting

\section{INTRODUCTION}

Indonesia is a tropical country with high humidity, which causes the Aedes aegypti mosquito to breed. The Aedes aegypty mosquito that causes dengue hemorrhagic fever (DHF) is an urban endemic disease that is a public health problem. Dengue Hemorrhagic Fever (DHF) is an endemic disease caused by the dengue virus with the Aedes aegypti mosquito vector and is still a health problem in Indonesia.

Dengue Hemorrhagic Fever is caused by the Dengue virus from the genus Flavivirus, family Flaviviridae. DHF is transmitted to humans through the bite of an Aedes mosquito infected with the Dengue virus. Dengue virus that causes Dengue Fever (DD), Dengue Hemorrhagic Fever (DHF) and Dengue Shock Syndrome (DSS) is included in group B Arthropod Virus (Arbovirosis) which is now known as the genus Flavivirus, family Flaviviridae, and has 4 types of serotypes, namely: -1, Den-2, Den-3, Den-4 (Kesehatan, 2018)

The East Java Health Office released data that in 2021 there were 408 cases and 5 people died, in January 2021 (Agriesta, 2021). So that cases do not continue to rise, the public must continue to be given education and ways to prevent dengue. The easiest way to eradicate dengue is to eradicate vectors to break the chain of transmission, but there are still many cases of dengue fever that occur when the Ministry of Health has attempted various activities such as spraying insecticides, PSN and abatization.

The increase in dengue cases in Indonesia has made many manufacturers create mosquito repellent products to tools and drugs that can kill mosquitoes with various types of products and brands. However, many products sold in the market can be said to be not good for health because 
they contain a lot of insecticides or other chemicals that are less environmentally friendly. reduction of negative impacts by using herbal ingredients that are able to repel mosquito bites.

DHF is a disease caused by the dengue virus which is transmitted through the bite of the Aedes aegypti and Aedes albopictus mosquitoes. These two types of mosquitoes are found in almost all corners of Indonesia, except in places with an altitude of more than 1000 meters above sea level (Kesehatan, 2018).

So that the most effective way to avoid DHF is to take early prevention as has been done and described above. In addition to eradicating the presence of the Aedes aegypti mosquito, the use of medicinal plants that grow around the house is also the best solution to avoid dengue. One of the medicinal plants that can be used to prevent and help treat dengue is citronella (Cymbopogon nardus).

Lemongrass is a plant surnamed Andropogon, with the species name Andropogon nardus $L$. Lemongrass is an erect, chronic grass plant that has very deep and strong roots. The stems form clumps, short, massive and round. The cross section of the stem is red. Lemongrass leaves are single leaves, complete and the leaf midrib is cylindrical, glabrous, often the inner surface is red, the tip of the tongue (ligula), strands, more than half hanging, squeezed with an aromatic smell. The arrangement of flowers panicles or compound grains, stemmed or sitting, leafy protective real, usually the same color generally white.

Lemongrass has antibacterial activity that can be used for wound treatment because Staphylococcus aureus bacteria are often found in injured skin tissue, including burns (Healy, 2006). Lemongrass essential oil is made in the form of a gel preparation that can hold and create a moist environment around the wound so that it can accelerate wound healing (Boateng, 2008). The main content of lemongrass is essential oil with components of citronellal $32-45 \%$, geraniol $12-18 \%$, citronellol 11-15\%, geranil acetate 3-8\%, citronellyl acetate 2-4\%, citral, kavikol, eugenol, elemol, kadinol, kadinen, vanillin, limonene, kamfen. Lemongrass oil contains 3 main components, namely citronellal, citronellol and geraniol (Wardani, 2009).

\section{METHOD}

The method of implementing this activity is through psychoeducation. Participants are given exposure to material about dengue hemorrhagic fever (DHF) and planting lemongrass together as an effort to prevent the breeding of the Aedes aegypti mosquito. This activity is carried out offline or face to face with a limit on the number of participants and a health protocol that has been coordinated with the school, namely SMK 17 Agustus 1945 Surabaya. The presentation of the material began by explaining the spread of dengue hemorrhagic fever (DHF) in Indonesia where many people died from the disease. Furthermore, it is also explained about the symptoms and phases of a person who is sick with dengue hemorrhagic fever (DHF). There is a phase that should be watched out for so that it should not be ignored because of the risk of death. The presenter will also invite all participants to share stories if they have experiences or have their families who have been sick with dengue hemorrhagic fever (DHF). The next explanation is about the efforts made for prevention starting from the 3M Movement which consists of closing, draining, and burying objects that support the mosquito life cycle to chemical prevention. The next explanation is about lemongrass as a mosquito repellent plant. The material is not only about lemongrass as a mosquito repellent but also explains other benefits of lemongrass itself. The presenters also conveyed in detail the content contained in the lemongrass plant and how lemongrass can repel mosquitoes.

The activity of planting lemongrass together, started after all participants were given an understanding of lemongrass. Before starting to practice how to plant lemongrass, Alicia and students first explained about the materials needed, namely: lemongrass seeds that have been 
cultivated in water before planting in dry soil, pots or polybags, soil and gloves. The materials that are already available are distributed to all participants. The lemongrass planting process was carried out simultaneously, guided by Alicia and students. This lemongrass plant will later be brought home by each participant.

All participants filled out the pre-test and post-test sheets before and after this activity. The data was taken to find out the differences in participants' understanding before the activity or counseling took place. The data is also used as evaluation data for students.

In accordance with the purpose of organizing this activity, the core of the implementation of this activity is to provide counseling related to dengue hemorrhagic fever (DHF) and how to use lemongrass as a prevention effort.

Table 1. Lemongrass planting movement

\begin{tabular}{|c|c|}
\hline Name of Activity & Planting lemongrass (mosquito repellent plant) \\
\hline Material & $\begin{array}{l}\text { Pollybag material, soil, lemon grass seeds, plastic gloves and } \\
\text { newspaper for the base }\end{array}$ \\
\hline Objective & $\begin{array}{l}\text { - Participants understand the ingredients needed to grow } \\
\text { lemongrass } \\
\text { - Participants understand and can directly practice the } \\
\text { lemongrass planting process }\end{array}$ \\
\hline \multirow[t]{4}{*}{ Stages } & $\begin{array}{l}\text { - Previously, lemongrass seeding had been carried out for } \\
\text { the previous week, namely by soaking lemongrass in water } \\
\text { until roots grew. }\end{array}$ \\
\hline & $\begin{array}{l}\text { - Prepare the soil that has been mixed with fertilizer and } \\
\text { start putting the soil into polybags. Only part of the soil is } \\
\text { added and the soil is compacted by pressing. }\end{array}$ \\
\hline & $\begin{array}{l}\text { - Lemongrass plants are put into polybags and begin to be } \\
\text { planted in the soil that was previously inserted }\end{array}$ \\
\hline & $\begin{array}{l}\text { - Add soil and compact again until the lemongrass stalks are } \\
\text { planted perfectly }\end{array}$ \\
\hline
\end{tabular}

\section{RESULTS}

The community service program related to the prevention of dengue hemorrhagic fever by planting lemongrass as an effort to prevent the occurrence of dengue hemorrhagic fever was carried out on:

Day/date : Wednesday, 28 April 2021

Time: $08.00-11.00$

Number of participants: 21 students

Place : SMK 17 August 1945 Surabaya

This community service program related to the prevention of dengue hemorrhagic fever by planting lemongrass was delivered to SMK students through several methods, namely, each participant filled out a pretest sheet containing several questions aimed at measuring initial 
knowledge or before delivering material about the dangers of fever. dengue and the benefits of lemongrass. Then the method in delivering material related to the definition, prevalence, causes, symptoms of dengue hemorrhagic fever and material about the benefits and how to grow lemongrass. In addition to delivering material about the benefits of lemongrass, the participants also carried out a movement to plant lemongrass together using a variety of materials that had been provided, such as polly bags, soil, lemongrass plants. Furthermore, the distribution of posttest sheets which aim to measure participants' knowledge after the material is delivered.

\section{DISCUSSION}

Based on community service activities regarding the prevention of dengue hemorrhagic fever by planting lemongrass, an evaluation of the activities can be seen through the number of attendances, in which all invited participants were present. In addition, the evaluation was carried out using the post-test method and the Lemongrass Planting Movement together. The post-test method was carried out by giving a questionnaire and several questions to the participants. The questionnaire contains several questions that must be answered by the participants and several questions are given to several participants with the aim of knowing the participants' understanding and knowledge regarding the material that has been presented. Then in conducting the evaluation, an observation method was also carried out when the activities of the lemongrass planting movement were carried out together.

The results of this community service program can increase the knowledge of SMK 17 August 1945 students about preventing dengue hemorrhagic fever by planting lemongrass. This is indicated by an increase in the value before the community service program was carried out with a percentage increase of $64.3 \%$. In addition, through the activities of planting lemongrass together, the participants or students are able to practice the lemongrass planting movement.

This community service is one of the efforts to increase students' knowledge so that they can understand the dangers of dengue fever and how to prevent dengue fever by planting mosquito repellent plants, namely lemongrass. According to research conducted by (Supartha, 2008) it is stated that ethanol extract from the leaves and stems of the lemongrass plant can be used as a vegetable pesticide that is useful for controlling the Aedes aegypti mosquito. Through this knowledge, students can avoid dengue hemorrhagic fever. In addition, this activity can also help students to protect their family members by taking early prevention to repel mosquitoes, especially mosquitoes that can cause dengue hemorrhagic fever. This is supported by research conducted by (Setiyawan et al., 2019) which shows that the results of their research show that counseling activities for dengue hemorrhagic fever and mosquito repellent plants can increase public knowledge about the dangers of dengue fever and the benefits of mosquito repellent plants. A similar study was also conducted by (Candra, 2010) in which the results of his research stated that there was an increase in knowledge, awareness and efforts to carry out a prevention by planting lemongrass as a mosquito repellent plant.

\section{CONCLUSION AND RECOMMENDATIONS}

Based on the implementation of the community service program, it can be concluded that there was an increase in students' knowledge about the dangers of dengue hemorrhagic fever and prevention of dengue hemorrhagic fever by planting lemongrass. In addition, students can understand and do lemongrass planting properly and correctly. Community service programs related to the prevention of dengue hemorrhagic fever by planting lemongrass are expected to be able to make students aware that a very simple movement such as planting lemongrass in their respective homes or even in the school environment is very important to avoid dengue 
hemorrhagic fever caused by dengue fever. Dengue virus is carried by the Aedes aegypti mosquito.

\section{ACKNOWLEDGMENTS}

We express our gratitude to Tuhan Yang Maha Esa because for the facilities provided so that this Community Service can run smoothly. We convey very special thanks because this community service can be carried out well with the support of (1) Rector of Universitas 17 Agustus 1945 Surabaya (2) Head of LPPM Universitas 17 Agustus 1945 Surabaya (3) Dean of Faculty of Psychology Universitas 17 Agustus 1945 Surabaya (4) Head of Departement of Professional Psychology Universitas 17 Agustus 1945 Surabaya (5) Head of SMK 17 Agustus 1945 Surabaya (6) Teachers and students of SMK 17 Agustus 1945 Surabaya.

\section{REFERENCES}

Agriesta, D. (2021). 408 Kasus Demam Berdarah Tercatat di Jatim Selama Januari, 4 di Antaranya Meninggal. Kompas.Com. https://regional.kompas.com/read/2021/02/10/20254601/408kasus-demam-berdarah-tercatat-di-jatim-selama-januari-4-di-antaranya

Boateng, B. A. (2008). Toksisitas Jatropha Seed Oil untuk Callosobruchus maculatus dan Perusahaan Parasitoid, Basalis Dinarmus. Journal of Applied Sciences, 4(8), 945-951.

Candra, A. (2010). Demam Berdarah Dengue: Epidemiologi, Patogenesis, dan Faktor Risiko Penularan. ASPIRATOR - Journal of Vector-Borne Disease Studies, 2(2). http://ejournal2.litbang.kemkes.go.id/index.php/aspirator/article/view/1787

Healy, B. F. (2006). ABC of Wound Healing: Infections. BMJ, 332, 838.

Kesehatan, K. (2018). Pusat Data dan Informasi - Kementerian Kesehatan Republik Indonesia. Kementrian Kesehatan RI. https://pusdatin.kemkes.go.id/article/view/19010400002/situasidemam-berdarah-dengue-di-indonesia.html

Setiyawan, H., Lestari, A. S., Ayuningtyas, E. N., Meradji, A., Diana, E., \& Utami, E. B. (2019). Penyuluhan Demam Berdarah Dengue (Dbd) Dan Tanaman Pengusir Nyamuk Di Desa Modalan, Banguntapan. Jurnal Pemberdayaan: Publikasi Hasil Pengabdian Kepada Masyarakat, 3(2), 241. https://doi.org/10.12928/jp.v3i2.849

Supartha, I. W. (2008). Pengendalian Terpadu Vektor VirusDemam Berdarah Dengue, Aedes aegypti(Linn.) dan Aedes albopictus(Skuse)(Diptera: Culicidae). Seminar DiesUnud2008.

Wardani, S. (2009). Uji Aktivitas Minyak Atsiri Daun dan Batang Serai (Andropogon Nardus L) sebagai Obat Nyamuk Elektrik Terhadap Nyamuk Aedes Aegypti. Pusat Studi Farmasi UMS, $1-60$. 